\title{
Giant aneurysm of right sinus of valsalva in a HIV-infected patient with extrapulmonary tuberculosis
}

Soumya Patra, ${ }^{1}$ Ravindranath K Shankarappa, ${ }^{1}$ Navin Agrawal, ${ }^{1}$ Madhav Hegde ${ }^{2}$

${ }^{1}$ Department of Cardiology, Sri Jayadeva Institute of Cardiovascular Sciences and Research, Bangalore, India ${ }^{2}$ Department of Cardiac CT, Sri Jayadeva Institute of Cardiovascular Sciences and Research, Bangalore, India

\section{Correspondence to} Dr Navin Agrawal, drnavinagrawal@gmail.com

\section{DESCRIPTION}

A 46-year-old male patient admitted with fever, cough, chest pain and dyspnoea during the past
7 days. He had a history of unprotected sexual exposure and was previously undiagnosed for HIV infection. Chest X-ray revealed bilateral pleural

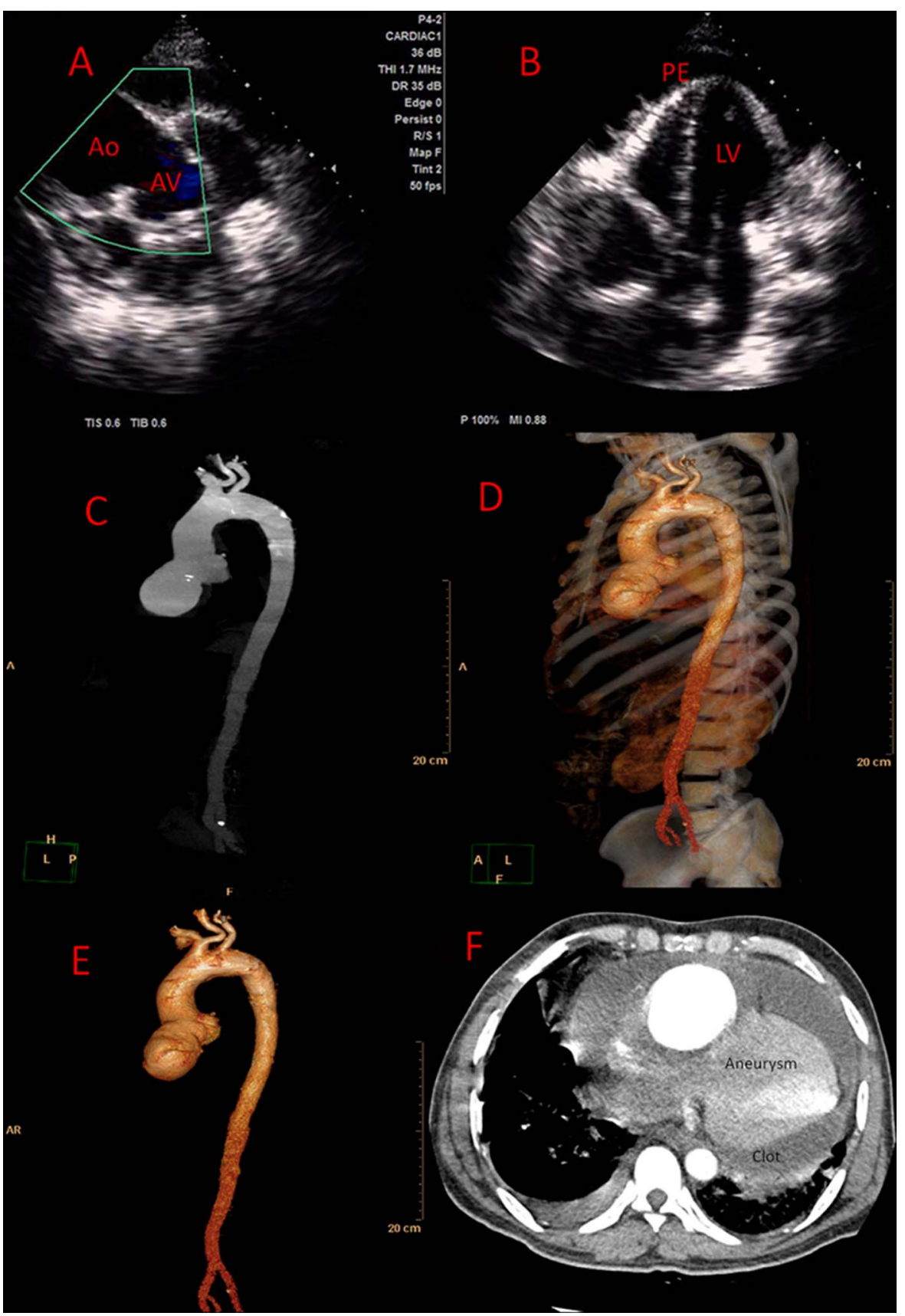

Figure 1 (A and B) The aortic short axis view showed a dilated and aneurysmal ascending aorta and the apical five chamber view showed the presence of pericardial effusion, mostly at the left ventricular (LV) apex; (figure 1-F) CT aortogram and $3 \mathrm{D}$ reconstructed images showed a giant aneurysm at the right sinus of valsalva $(7.1 \times 8.5 \mathrm{~cm})$ with a clot inside. 
effusion along with cardiomegaly. ECG showed sinus tachycardia with low-voltage complex. Blood investigation revealed haemoglobin-10.4 g/dL, total leucocyte count $8600 / \mathrm{mm}^{3}$, platelets $215000 / \mathrm{mm}^{3}$ with normal liver and renal function test. 2D echocardiography demonstrated moderate pericardial effusion, normal biventricular function with dilated and aneurysmal ascending aorta and mild aortic regurgitation (figure 1A,B). Pleural fluid aspiration showed straw coloured fluid with total cell count 600 (lymphocytic), exudative and very high adenosine deaminase level (ADA $86 \mathrm{U} / \mathrm{L}$ ). Serological investigation confirmed the presence of HIV infection. The patient was started on antitubercular therapy. CT aortogram confirmed the presence of a giant $(7.1 \times 8.5 \mathrm{~cm})$ aneurysm of the right sinus of valsalva (figure $1 \mathrm{C}-\mathrm{F}$ ). The patient was unwilling to undergo surgery of the aneurysm of the right sinus of valsalva.

The differential diagnosis of the aneurysm of the sinus of valsalva could be Marfan's syndrome, vasculitis due to tuberculosis, syphilis and other infectious agents, rheumatological diseases and HIV-associated vasculitis. ${ }^{1}$ Only few cases of aneurysm of the aorta due to HIV infection have been reported in the literature and the histopathology of the resected aorta revealed a granulomatous giant cell mesaortitis. ${ }^{2} 3$ So far this is the biggest aneurysm associated with HIV.

\section{Learning points}

- HIV-associated vasculitis rarely involves the sinus of valsalva-causing aneurysm.

- The differential diagnosis of aneurysm of the sinus of valsalva could be Marfan's syndrome, vasculitis due to tuberculosis, syphilis and other infectious agents, rheumatological diseases and HIV-associated vasculitis.

- Histopathology of the resected aorta usually revealed a granulomatous giant cell mesaortitis.

Competing interests None.

Patient consent Obtained.

Provenance and peer review Not commissioned; externally peer reviewed.

\section{REFERENCES}

1 Boggian K, Leu HJ, Schneider J, et al. True aneurysm of the ascending aorta in HIV disease. Schweiz Med Wochenschr 1994;124:2083-7.

2 Mirza H, Patel P, Suresh K, et al. HIV disease an atherosclerotic ascending aortic aneurysm. Rev Cardiovasc Med 2004;5:176-81.

3 Choi JB, Yang HW, Oh SK, et al. Rupture of ascending aorta secondary to tuberculous aortitis. Ann Thorac Surg 2003;75:1965-7.

Copyright 2013 BMJ Publishing Group. All rights reserved. For permission to reuse any of this content visit

http://group.bmj.com/group/rights-licensing/permissions.

BMJ Case Report Fellows may re-use this article for personal use and teaching without any further permission.

Become a Fellow of BMJ Case Reports today and you can:

- Submit as many cases as you like

- Enjoy fast sympathetic peer review and rapid publication of accepted articles

- Access all the published articles

- Re-use any of the published material for personal use and teaching without further permission

For information on Institutional Fellowships contact consortiasales@bmjgroup.com

Visit casereports.bmj.com for more articles like this and to become a Fellow 